special colleges and institutes connected with agriculture (Warsaw, Pulawy and Bydgoszcz), mining (Cracow) and veterinary science (Lwów), in addition to various scientific academies and societies in different centres.

IT is doubtful whether these centres of science will function again before the end of hostilities, and even if some attempt were made to utilize them it will not be for Polish science and culture, since the unhappy nation is again witnessing a partition, the fourth, of the State. From what appears to be the intention of Poland's invaders, Germany will gain possession of the seats of learning at Warsaw (the university is in the western half of the city), Cracow, Bydgoszcz and Poznań, whilst those of Lublin and Lwów will pass into Russian hands. The fate of Vilno and its university and cultural institutes is not certain, since the possibility of its return to Lithuania must not be excluded. Our sympathy goes out to the many men of science in Poland whose work has been interrupted and who have to suffer the horrors of a modern war in which they aro the victims of unprovoked aggression.

\section{Patents in War Time}

VArious Acts of Parliament and statutory rules control the issue of patents. They lay down definite time limits within which certain things must be done by an inventor who is applying for a grant. For example, the complete specification must bo filed not later than twelve months after the pro. visional, and the application as a whole must have reached the stage of being "in order for acceptance" not later than eighteen months after the earliest filing date. In the same way renewal fees must be paid promptly as they fall due, or the patent will lapse. Extensions of time varying from one to three months can be obtained on payment of stipulated fees, but after that no extensions are allowed. In the Electrical Review of September 22, 8 "Legal Correspondent" writes an instructive article on the effects of the new patent legislation. The 'intellectual property' which is created by the operation of the patent system, as well as the artistic property which is called copyright, both stand in a class apart from the ordinary trade and business of mankind. It is therefore for the benefit of all that they should be safe. guarded even when they como from an enemy source.

The changes to be made in patent procedure, in order to meet the abnormal conditions of war, are set out in the new Patents, Designs, Copyright and Trade Marks (Emergency) Bill, to which the Royal Assent was given on September 21. The first clause of the Act states that any existing license granted under a patent does not become invalid simply because the proprietor or owner of the patent is an enemy. Clause 4 of the Bill preserves the right of an enemy, even during the period of hostilities, to apply for the grant of a British patent. At the end of the war of 1914-18, the sudden release of patents claiming priority-dates, which in some cases went back for five or six years before the specifications were formally accepted and published, naturally created considerable confusion and embarrassment. When the next armistice comes, we may reasonably expect that the experienco gained in similar problems twenty years ago will stand us in good stead.

\section{Food Production in War Time}

THe Agricultural Research Council is to work in the closest co-operation with the Ministry of Agriculture and the Department of Agriculture for Scotland in connexion with research and investigations into problems that may arise from the food production campaign. Since March last a committee of the Agricultural Research Council has had under examination the programmes of research and the qualifications of the staffs of agricultural research institutes from the point of view of an emergency. It will be the function of the Council now to guide the research at these institutes into the special agricultural problems arising out of war conditions. For this purpose the chairman of the Agricultural Research Council (Sir Thomas Middleton) has, with the approval of the Lord President of the Council, appointed a small executive committee, which will keep all nembers of the Council in close touch with the situation.

The Minister of Agriculture and Fisheries has also constituted an advisory panel the members of which will bo available for consultation, as need arises, on the immediate technical problems of war-time food production which do not call for further réscarch. The members of the panel are: Prof. F. L. Engledow (cereals and crops), Prof. J. A. Hanley (soils), Prof. H. D. Kay (dairying), Sir John Russell (plant nutrition), Prof. J. A. Scott Watson (general agriculture), Sir George Stapledon (grassland), Dr. 'T'. Wallace (nutrition of horticultural crops), Dr. S. J. Watson (grass and fodder conservation), and $\mathrm{Dr}$. H. E. Woodman (livestock and nutrition). The Secretary of State for Scotland will consult the agricultural colleges and the research institutes in Scotland on any technical questions on which their advice may be desired.

\section{The Spirit of Adventure}

There is no greater need in our time than the development of the capacity to weigh evidence and form sound judgments, and, having formed indepen. dent judgments, to have the reliance to stand by them. Although the main objects of Surgeon-Commander G. Murray Levick in leading expeditions of school-boys into uninhabited wilds is to widen outlook and to foster the spirit of adventure, one of the chief results must be the encouragement of independence and self-reliance; and no praise can be too high for the enthusiasm and skilled planning which has induced him to shoulder the responsibility of organizing and conducting seven such expeditions for the Public Schools Exploring Society which he founded in 1932. Three of the expeditions have been to Lapland and four to Newfoundland, which affords just those great areas of unmapped and uninhabited country which suit the needs of the young explorers.

(Continued on page $\mathbf{5} S 9$. 